\title{
The effect of aloe preparation and 5-oxo-1,2,4-triazine on immunological and haematological indices of blood of turkey hens subjected to stress
}

\author{
Katarzyna Ognik, Iwona Sembratowicz, Anna Czech \\ University of Life Sciences in Lublin, Faculty of Animal and Breeding, \\ Department of Biochemistry and Toxicology, Lublin, Poland
}

Received October 27, 2014

Accepted November 10, 2015

\begin{abstract}
The aim of this study was to determine the effect of aloe extract or 5-oxo-1,2,4-triazine on immunological and haematological indices during artificially induced stress in turkey hens. The experiment was carried out on 360 turkey hens (6 groups). The groups $\mathrm{C}$ and $\mathrm{C}+$ stress were the control groups and did not receive any additive. Birds from the groups $\mathrm{A}$ and $\mathrm{A}+$ stress were administered aloe extract at the amount of $0.70 \mathrm{ml} / \mathrm{kg}$ body weight (bw)/day. The turkey hens from the groups $\mathrm{T}$ and $\mathrm{T}+$ stress received 5-oxo-1,2,4-triazine at the amount of $30 \mu \mathrm{g} / \mathrm{kg}$ bw/day. The additives were administered in the birds' drinking water twice for 28 days (days 36-63 and 78-105) of the birds' life. On days 61-63 and 103-105 a stress factor (simultaneous crowding and a change in temperature and lighting) was introduced in the groups $\mathrm{C}+\mathrm{stress}$, $\mathrm{A}+$ stress and $\mathrm{T}+$ stress for 1 hour a day. The results showed that the applied stress factors caused a significant $(P \leq 0.05)$ decrease in the lysozyme level and \% phagocytic cells, as well as a non-significant reduction in the metabolic activity of heterophils. Under the influence of stress an increase $(P \leq 0.05)$ in the percentage of monocytes and basophils was observed. The use of aloe preparation improved some indicators of immunity (increased, $P \leq 0.05$, lysozyme and $\%$ phagocytic cells) in the turkey hens. To alleviate the negative effect of stress on immune reactions, supplementation of diets with aloe extract supplemented with resveratrol and vitamin $\mathrm{C}$ may be considered.
\end{abstract}

Poultry, stressors, supplements, immunity

The response of the immune system to stress may vary depending on the type and intensity of stress factors and the time of exposure. Stress conditions may inhibit or stimulate the immune response, change its type, and modulate autoimmune phenomena (Zimecki and Artym 2004). Stress factors can also modify the morphology of blood - both white blood cell and red blood cell indices (Qureshi et al. 2002). To counteract the adverse effects of stress on the defensive reactions and morphology of the blood of birds, it is advisable to use immunostimulating and biostimulating preparations, both synthetic and natural. Among natural immunostimulants, herbal preparations prepared from the coneflower, garlic, aloe and other plants have an important role in animal feeding (Ognik et al. 2013). The immunostimulatory properties of aloe extracts have been confirmed in studies on turkeys (Ognik and Sembratowicz 2012a). Improvements in haematological and immunological indices in turkeys have also been demonstrated for the newly-synthesized amidrazone derivative 5-oxo-1,2,4-triazine (Ognik and Sembratowicz 2009). This compound exhibits anti-inflammatory, antibacterial, antiviral, and antifungal (in vitro analysis) properties (Modzelewska-Banachiewicz and Kamińska 2000).

Taking into account the biological properties of aloe extracts and the newly synthesized amidrazone derivative 5-oxo-1,2,4-triazine, the aim of this study was to determine their effect on immunological and haematological indices during artificially induced stress in turkey hens. 
Materials and Methods

Experimental design

This experiment presents a part of the results collected from a large clinical trial on the effect of aloe preparation and 5-oxo-1,2,4-triazine on blood variables of turkey hens subjected to stress.

The experiment was carried out on 360 turkey hens of the BUT-9 line, aged from 6 to 16 weeks. The birds were randomly assigned to 6 experimental groups of 60 birds (Table 1). Each group was further subdivided into 6 replicates, each with 10 birds. The experimental procedure was approved by the Second Local Ethics Commission for Experiments with Animals in Lublin (Approval No. 11/2009). During the experimental period, birds from all groups had access to drinking water and were fed ad libitum with complete feed mixtures balanced according to the nutrient requirements for poultry (NRP 2005).

Table 1. Experimental design.

\begin{tabular}{|c|c|c|c|c|c|}
\hline \multirow[t]{2}{*}{ Day of life } & Control & \multicolumn{4}{|c|}{ Experimental groups } \\
\hline & C C+stress & A & $\mathrm{A}+$ stress & $\mathrm{T}$ & $\mathrm{T}+$ stress \\
\hline $36-63$ & - & $\begin{array}{l}\text { aloe extract } \\
(0.70 \mathrm{ml} / \mathrm{kg} \mathrm{bw} / \text { day })\end{array}$ & $\begin{array}{l}\text { aloe extract } \\
(0.70 \mathrm{ml} / \mathrm{kg} \text { bw/day })\end{array}$ & $\begin{array}{l}\text { 5-oxo-1,2,4-triazine } \\
(30 \mu \mathrm{g} / \mathrm{kg} \mathrm{bw} / \text { day })\end{array}$ & $\begin{array}{l}\text { 5-oxo-1,2,4-triazine } \\
(30 \mu \mathrm{g} / \mathrm{kg} \text { bw/day })\end{array}$ \\
\hline $61-63$ & - $\quad+$ stress & - & + stress & - & + stress \\
\hline $64-77$ & - & - & - & - & - \\
\hline $78-105$ & - & $\begin{array}{l}\text { aloe extract } \\
(0.70 \mathrm{ml} / \mathrm{kg} \mathrm{bw} / \text { day })\end{array}$ & $\begin{array}{l}\text { aloe extract } \\
(0.70 \mathrm{ml} / \mathrm{kg} \mathrm{bw} / \text { day })\end{array}$ & $\begin{array}{l}\text { 5-oxo-1,2,4-triazine } \\
(30 \mu \mathrm{g} / \mathrm{kg} \text { bw/day) }\end{array}$ & $\begin{array}{l}\text { 5-oxo-1,2,4-triazine } \\
(30 \mu \mathrm{g} / \mathrm{kg} \text { bw/day })\end{array}$ \\
\hline $103-105$ & - + stress & - & + stress & - & + stress \\
\hline
\end{tabular}

Groups $\mathrm{C}$ and $\mathrm{C}+$ stress were control groups that did not receive any additive. Birds from groups Aand $\mathrm{A}+\mathrm{stress}$ were administered aloe extract (Aloes Plus, Herbapol Lublin, Poland) with trans-resveratrol and vitamin Cadded at the amount of $0.70 \mathrm{ml} / \mathrm{kg}$ body weight (bw)/day. The applied dosage was chosen on the basis of previous studies (Ognik and Czech 2010; Ognik and Sembratowicz 2012). Its main active compounds were resveratrol $(486.3 \mathrm{mg} / \mathrm{l})$ and vitamin $\mathrm{C}(35.12 \mathrm{mg} / \mathrm{l})$. The turkey hens from groups $\mathrm{T}$ and $\mathrm{T}(+)$ stress received the amidrazone derivative 5-oxo-1,2,4-triazine at the amount of $30 \mu \mathrm{g} / \mathrm{kg}$ bw/day, dissolved in a small quantity of ethanol (about $2 \mathrm{ml}$ ). The applied dosage was chosen on the basis of previous studies (Sembratowicz et al. 2004; Ognik and Sembratowicz 2009; Ognik and Sembratowicz 2011). The 5-oxo-1,2,4triazine was synthesized by the Department of Organic Chemistry of the Medical University of Lublin. The additives were administered to the birds in their drinking water for 28 days starting from the $36^{\text {th }}$ day of life. The dose of the additives per $\mathrm{kg}$ bw/day was determined on the basis of mean values for performance indicators (body weight and daily weight gain) in BUT-9 turkey hens. The experimental additives were administered every morning in drinking troughs with about 1-2 litres of water, which guaranteed that the additives would be consumed, and then clean drinking water was added as needed. A two-week break followed, during which the birds drank water without additives. After the break, the birds again received additives for further 28 days. On days 26, 27, and 28 (61-63 days of life) of administration of additives an experimental factor in the form of stress stimuli was introduced in groups $\mathrm{C}+$ stress, $\mathrm{A}+$ stress and $\mathrm{T}+$ stress for 1 hour each day. The stress stimuli were crowding and changes in temperature and lighting, applied simultaneously. The birds were placed in $85 \times 50 \times 35 \mathrm{~cm}$ plastic containers (crowding) used to transport birds. A maximum of three birds were placed in one container. The containers had holes enabling access to cool fresh air when the birds were moved outdoors (to a place not shielded from wind) in order to induce a rapid change in lighting conditions from artificial light to daylight, as well as a decrease in temperature of about $20-30{ }^{\circ} \mathrm{C}$, as during the study (November-January) the outside air temperature ranged from $+5^{\circ} \mathrm{C}$ to $-10{ }^{\circ} \mathrm{C}$. The treatments were conducted in the daytime, always at the same time of day. The experimental conditions were adjusted to resemble the conditions of the production process, particularly during intensive rearing at large production farms. The same procedure for inducing the stress factor was applied on days 103, 104, and 105 of the life of the turkey hens. On days 63 and 105 of the experiment, from 6:00 to 10:00 $\mathrm{h}$ the birds received experimental supplements and feed. Then from 10:00 $\mathrm{h}$ to 18:00 $\mathrm{h}$ there was an 8 -hour fasting period. Fasting is essential before collecting blood from birds. It was not an experimental element (stress). Birds in all groups received no feed for $8 \mathrm{~h}$, but for $7 \mathrm{~h}$ before the stress began at 17:00 $\mathrm{h}$ they had unlimited access to water. From 17:00 to 18:00 h the stress factor was introduced, immediately after which blood was collected for analysis. 
Sample collection and analytical method

At the end of the $63^{\text {rd }}, 77^{\text {th }}$ and $105^{\text {th }}$ day of life of the turkey hens, blood was collected (by a veterinarian) from the wing vein of 10 birds from each group. Blood samples were taken after 8-hour fasting with free access to drinking water. An aqueous solution of heparin sodium salt at $0.01 \mathrm{ml}$ per $1 \mathrm{ml}$ blood was used to stabilize the blood samples. Haematocrit value $(\mathrm{Ht})$, haemoglobin concentration $(\mathrm{Hb})$, total white blood cell count (WBC) and percentages of white blood cells (leukogram) were determined by standard methods according to Bomski (1989). The immunological analyses involved determination of phagocytic activity of leukocytes against the Staphylococcus aureus 209P strain, expressed as the percentage of phagocytic cells (\% PC) and phagocytic index (PI) (Siwicki et al. 1994). The respiratory burst activity of the heterophils was quantified by nitroblue tetrazolium reduction (NBT) to formazan as a measurement of production of oxygen radicals (Park et al. 1968). Serum lysozyme activity was determined by the turbidimetric method (Siwicki and Anderson 1993).

Statistical analyses

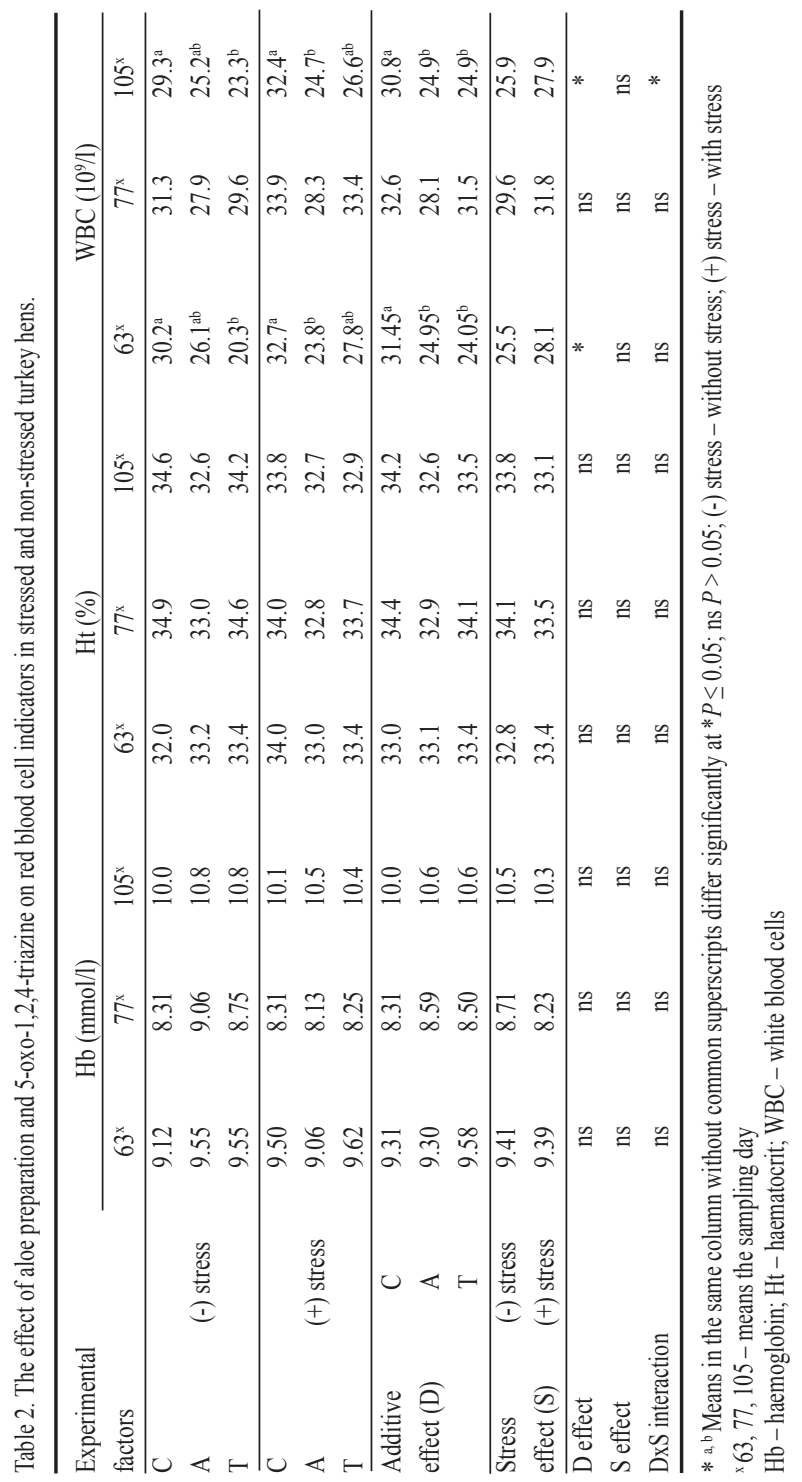

The data obtained were analysed using the STATISTICA software package, version 6.0 (StatSoft Corp., Kraków, Poland). Two-way repeated measures ANOVA was applied to assess the effect of the main factors, i.e. stress (S) and additives (D), and their interactions $(\mathrm{S} \times \mathrm{D})$. When the analysis revealed a significant interaction or that both factors had a significant influence, the differences between individual groups were then analysed using Tukey's multiple range post hoc test. The data were checked for normality before the statistical analysis was performed. Differences were considered significant at $P \leq 0.05$. The pooled SEM was calculated as the standard deviation from all measurements divided by their square root.

\section{Results}

Data presented in Table 2 indicate that the stress factors applied did not significantly affect red blood cell indices ( $\mathrm{Hb}$ concentration, $\mathrm{Ht}$ value) or total WBC count. However, the stressful stimuli did cause changes in the leukogram. In the stressed groups a slight $(P>0.05)$ increase in the $\mathrm{H} / \mathrm{L}$ ratio was observed in comparison to the groups not subjected to stress (Table 3). The percentage of monocytes and basophils in the stressed birds (but only in the $9^{\text {th }}$ week of life) was significantly $(P \leq 0.05)$ elevated compared to the untreated birds (Table 4). The break in the application of stress $\left(11^{\text {th }}\right.$ week of life) led to 


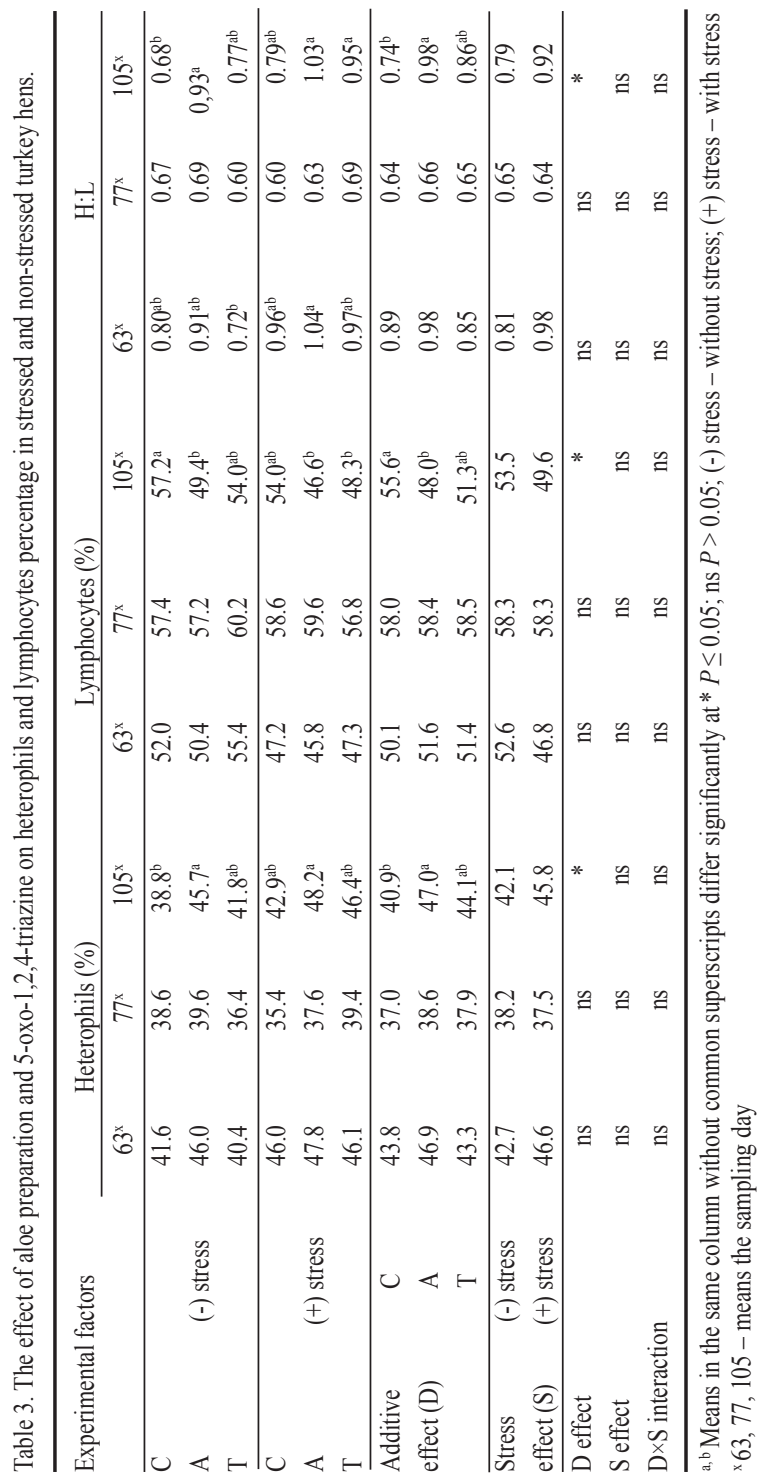

normalization of white blood cell indices. Neither of the additives, i.e. aloe preparation or 5-oxo1,2,4-triazine, had a significant effect on $\mathrm{Hb}$ concentration and $\mathrm{Ht}$ value, but they caused a decrease $(P \leq 0.05)$ in the total WBC count. In the $9^{\text {th }}$ week of life, in the groups receiving aloe (A) or 5-oxo1,2,4-triazine derivative (T), a significant $(P £ 0.05)$ decrease was noted in the percentage of monocytes, and in the case of aloe preparation, in the percentage of basophils as well (Table 4). The results of immunological analyses (Table 5) indicate a significant $(P \leq 0.05)$ suppressive influence of stress factors (in the $15^{\text {th }}$ week of life) on the activity of lysozyme in the blood serum and the percentage of phagocytic cells (\% PC). The respiratory burst activity of heterophils ( $\%$ NBTpositive cells) in stressed birds was also reduced compared to the untreated birds, but not significantly. Following administration of the aloe preparation, a significant $(P \leq 0.05)$ increase in lysozyme activity and \% PC was recorded. Supplementation with the aloe preparation also contributed to a slight increase in the metabolic activity of heterophils, measured by the NBT-reduction test. In contrast, 5-oxo-1,2,4-triazine had no significant effect on the immunological indices tested.

\section{Discussion}

The influence of stress on the functioning of the immune system of birds has not been sufficiently explored. Acute and chronic stresses may have different effects on the immune system. Chronic stress is generally treated as an immunosuppressive agent, possibly due to the direct inhibitory effect of glucocorticoids released in the course of the stress response (De Jong et al. 2001). In our study the stress factors applied in the form of crowding and changes in light and temperature caused suppression of some indices of innate immunity in the birds, both cellular (phagocytosis) and humoral (lysozyme activity in blood). These findings are in accordance with a study conducted by Mashaly et al. (2004), who 


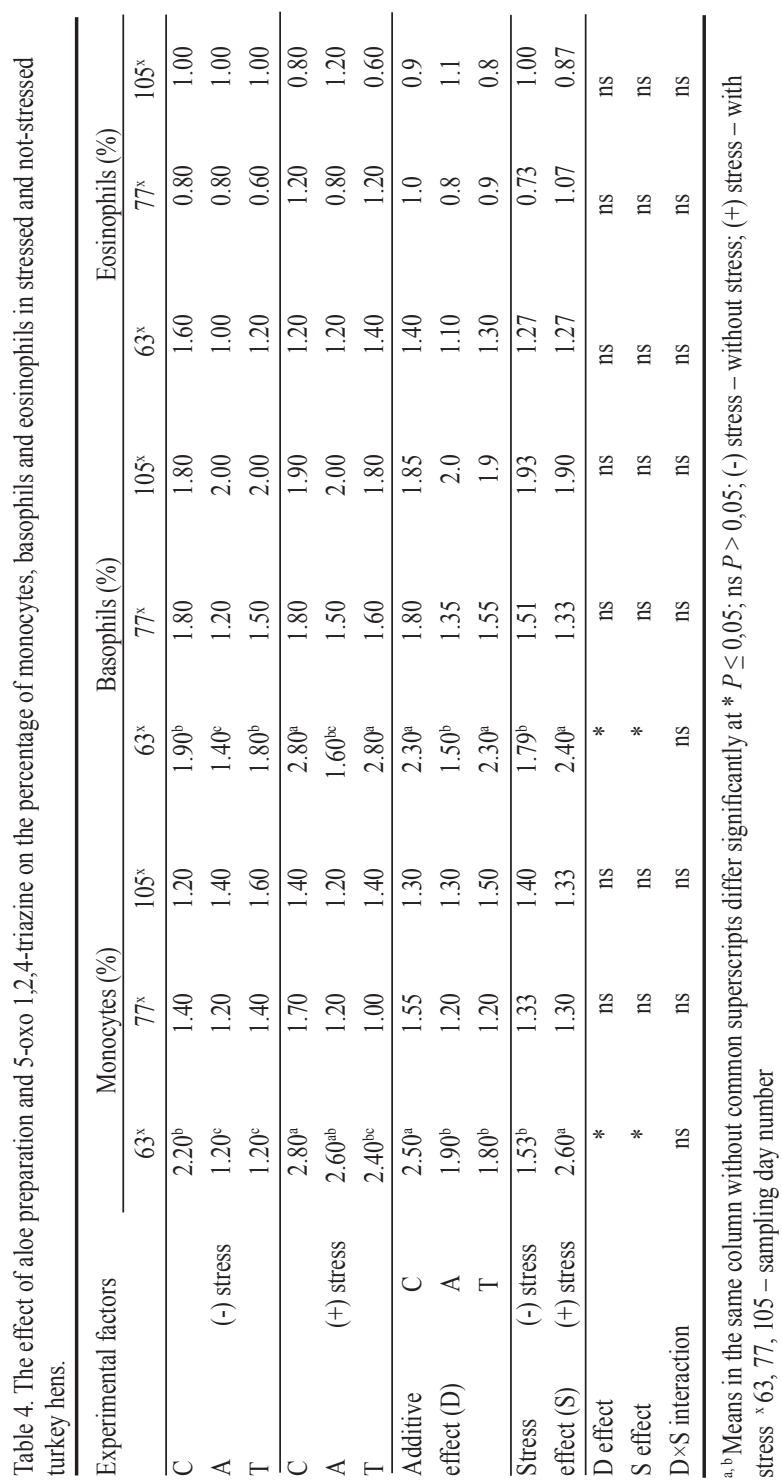

confirmed the suppressive effect of adrenal steroid hormones on the phagocytic ability of leukocytes. A decrease in blood concentrations of lysozyme in chickens during immobilization stress was observed by Fitko et al. (1992). After the release of lysosomal structures this enzyme enters plasma and its activity is treated as an indicator of phagocyte turnover. The obtained results showed that supplementation with 5-oxo1,2,4-triazine did not affect the examined immuninty indicators. In contrast, addition of the aloe preparation significantly stimulated some non-specific immunity indicators. Avian heterophils produce peroxide radicals that are instrumental in directly killing bacteria. Our study revealed that leukocytes of birds which received the aloe preparation produced greater amounts of these radicals, as evidenced by a slight increase in the percentage of heterophils reducing nitroblue tetrazolium. Results obtained by numerous authors (Ognik and Sembratowicz 2007; Akhtar et al. 2012; Ognik and Sembratowicz 2012a) have confirmed the beneficial effect of aloe extracts on the immune response in poultry. The immunostimulatory properties of the aloe preparation may be linked to the presence of acemannan polysaccharides in

aloe (Harlev et al. 2012), as well as the vitamin C included in the formulation, whose role in the immune reaction is well known. Ascorbic acid is necessary for phagocytic reactions to proceed properly, and also stimulates interferon synthesis and lymphocyte proliferation (Ortuño et al. 2001).

Results obtained by Ajakaiye et al. (2010) indicate that stress factors can affect the morphology of blood. A decrease in the total number of leukocytes, as well as lymphopaenia and granulocytosis, is most often observed. This results in an increase in the $\mathrm{H} / \mathrm{L}$ ratio, which is an important determinant of stress in birds (Ognik and Sembratowicz 2012b). Elevation of red blood cell indices, which results from increased erythropoiesis and 


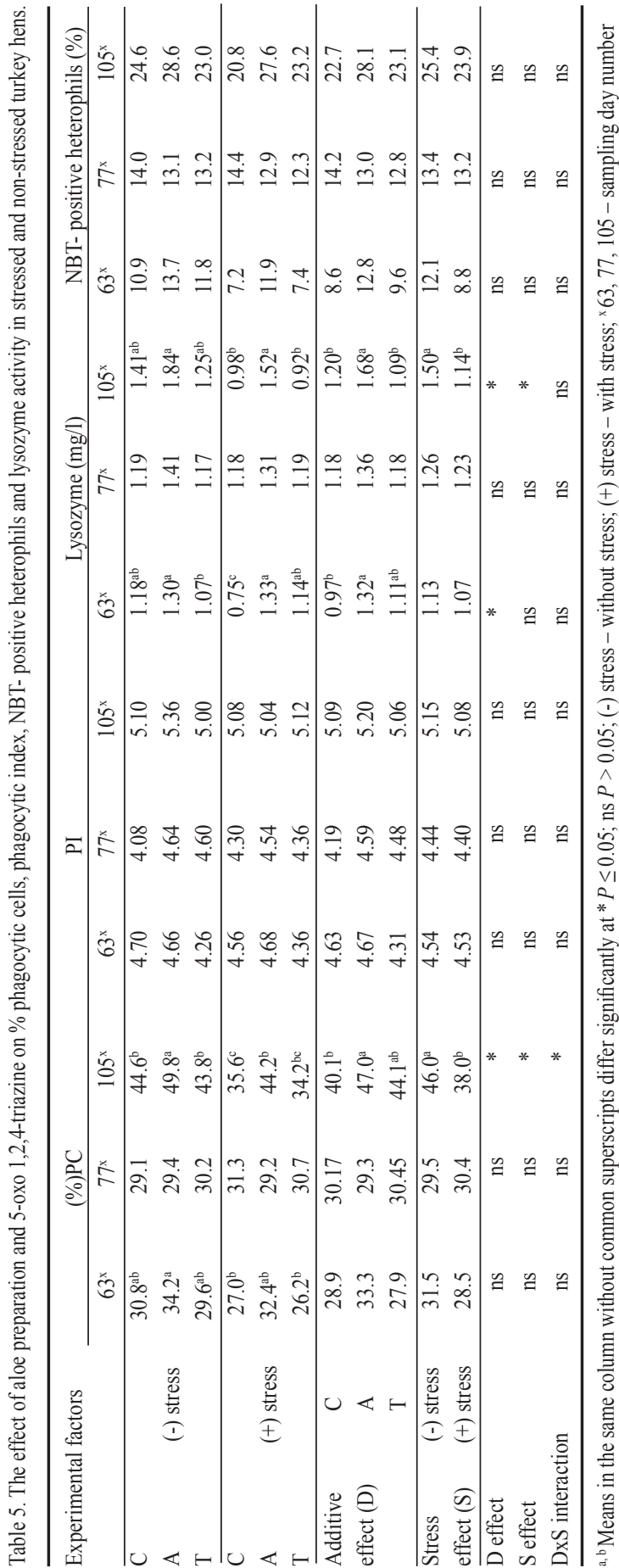

splenic contraction, may also be treated as an adaptation to increased oxygen demand during stress (McKay and Cidlowski 2003). The results of our study revealed that stress did not modify red blood cell indices or the total WBC count. However, exposure to stress significantly increased the percentage of monocytes and basophils. A slight elevation of the $\mathrm{H} / \mathrm{L}$ ratio in the stressed birds was also noted, which indicates the probable occurrence of stress, as also evidenced by the observed immunosuppression. Supplementation with the aloe preparation led to normalization of monocytes and basophils in the stressed birds. Application of the aloe preparation also resulted in a considerable increase in the percentage of heterophils, which confirms the immunostimulating properties of the components of the additive, as these cells play a key role in phagocytic reactions.

In conclusion, the results of this experiment demonstrate that the sudden change in temperature and light or excessive crowding of the turkey hens caused immunosupression and modified white blood cell indices. To alleviate the negative effect of stress, supplementation of diets with aloe extract to which resveratrol and vitamin $\mathrm{C}$ have been added may be considered.

\section{References}

Ajakaiye JJ, Joseph O, Ayo JA, Ojo SA 2010: Effects of heat stress on some blood parameters and egg production of Shika Brown layer chickens transported by road. Biol Res 43: 183-189

Akhtar M, Hai A, Awais MM, Iqbal Z, Muhammad F, Haq A, Anwar MI 2012: Immunostimulatory and protective effects of Aloe vera against coccidiosis in industrial broiler chickens. Vet Parasitol 25: $170-177$ 
Bomski J 1989: Elementary haematological analysis (in Polish). PZWL, Warszawa, 333 p.

De Jong IC, Sander van Voorst A, Erkens Jo HF, Ehlhardt DA, Blokhuis HJ 2001: Determination of the circadian rhythm in plasma corticosterone and catecholamine concentrations in growing broiler breeders using intravenous cannulation. Physiol Behav 74: 299

Fitko R, Jakubowski K, Roszko E, Zieliński H, Potrzuska I 1992: The level of corticosterone and immune parameters in chicken in immobilization stress and after application of immunomodulators (in Polish). Medicine Vet 48: 298-300

Harlev E, Nevo E, Lansky EP, Ofir R, Bishayee A 2012: Anticancer potential of Aloes: antioxidant, antiproliferative, and immunostimulatory attributes. Planta Med 78: 843-852

Mashaly MM, Hendricks GL, Kalama MA, Gehad E, Abbas O, Patterson P 2004: Effect of heat stress on production parameters and immune responses of commercial laying hens. Poultry Sci 83: 889-894

McKay LI, Cidlowski JA: Corticosteroids. In: Kufe DW, Pollock RE, Weichselbaum RR, et al., editors. HollandFrei Cancer Medicine. $6^{\text {th }}$ edn. Hamilton (ON): BC Decker; 2003. Chapter 62. Available at: http://www.ncbi. nlm.nih.gov/books/NBK12594/

Modzelewska-Banachiewicz B, Kamińska T 2000: Synthesis and biological action of 5-oxo-1,2,4-triazyne derivatives. Pharmazie 54: 503-505

NRP 2005: Nutrient Requirements for Poultry. Fourth edition revised and enlarged. Collective work (Rutkowski A, co-editor). PAN IFiZZ Jabłonna Poland, pp. 57-59

Ognik K, Sembratowicz I 2007: Influence of Biostymina and Bioaron C on some anti-oxidation and immune indices of turkey-hens' blood. Pol J Environ St 16 3A: 209-212

Ognik K, Sembratowicz I 2009: Influence of synthesized 5-oxo 1,2,4-triazyne derivative on some immunological and hematological indices of turkey. J Appl Anim Res 13: 235-237

Ognik K, Czech A 2010: The effect of diversified doses of aloes plus-a plant preparation on the level of antioxidant indices in the blood of turkey hens. J Appl Anim Res 38: 45-48

Ognik K, Sembratowicz I 2011: Influence of a newly-synthesised 5-oxo-1,2,4-triazyne derivative on antioxidant indices of blood and performance of turkey hens. South Afr J Anim Sci 41: 403-412

Ognik K, Sembratowicz 2012a: Effect of Aloe plus preparation supplement on hematological and immunological blood parameters and performance of turkey hens. Turkish J Vet Anim Sci 36: 1-8

Ognik K, Sembratowicz I 2012b: Stress as a factor modifying the metabolism in poultry. Ann UMCS s EE 30: $34-43$

Ognik K, Czech A, Stachyra K 2013: Effect of a natural versus a synthetic antioxidant, and sex and age on the redox profile in the blood of growing turkeys. South Afr J Anim Sci 43: 473-481

Ortuño J, Cuesta A, Angeles EM, Mesequer J 2003: Effect of oral administration of high vitamin C and E dosages on the gilthead seabream (Sparus aurata L.) innate immune system. Vet Immunol Immunopathol 30: 167-180

Park BH, Fikrig SM, Smithuick EM 1968: Infection and nitroblue tetrazolium reduction by neutrophils. Lancet 2: 532

Qureshi F, Alam J, Masood AK, Ghazala S 2002: Effect of examination stress on blood cell parameters of students in a Pakistani medical college. J Ayub Med Coll Abbottabad 14: 20-22

Sembratowicz I, Ognik K, Truchliński J, Modzelewska-Banachiewicz B 2004: The influence of 1,2,4-triazole and 5-oxo-triazyne derivatives on some indices of blood and performance of turkey hens. J Anim Feed Sci 13: $39-42$

Siwicki AK, Anderson DP 1993: Nonspecific defence mechanisms assay in fish. II. Potential killing activity of neutrophils and macrophages, lysozyme activity in serum and organs, and total immunoglobulin (Ig) level in serum. Fish Diseases Diagn. Prevent Methods. FAO-Project CGP/INT/526/JAN, FFI Olsztyn: 105-112

Siwicki AK, Anderson DP, Rumsey GL 1994: Dietary intake of immunostimulants by rainbow trout affects non-specific immunity and protection against furunculosis. Vet Immunol Immunopathol 41: 125-139

Zimecki M, Artym J 2004: The influence of psychic stress on immunity response (in Polish). Postępy Hig Med Dośw 58: 166-175 